\title{
Differential outcome of neurological HCMV infection in two hematopoietic stem cell transplant recipients
}

\author{
Anna Amelia Colombo ${ }^{1}$, Giovanna Giorgiani ${ }^{2}$, Vanina Rognoni ${ }^{3}$, Paola Villani ${ }^{4}$, Milena Furione ${ }^{3}$, \\ Mario Regazzi Bonora ${ }^{4}$, Emilio Paolo Alessandrino ${ }^{1}$, Marco Zecca ${ }^{2}$ and Fausto Baldanti ${ }^{3^{*}}$
}

\begin{abstract}
Background: Human cytomegalovirus (HCMV) infection of the central nervous system (CNS) is a rare but life threatening condition which may follow hematopoietic stem cell transplantation. Diagnosis, monitoring and treatment approaches rely on anecdotal reports.

Case presentations: The different outcomes of HCMV CNS disease in an adult and a pediatric T-cell depleted hematopoietic stem cell transplant (HSCT) recipient are reported. In the first case, HCMV encephalitis emerged in the context of simultaneous impairment of the T- and B-cell immunity. Antiviral treatment only reduced viral load in peripheral blood and the patient died. In the second case, an HCMV radiculopathy was observed and antiviral treatment was adjusted on the basis of intrathecal drug level. In addition, donor HCMV-specific cytotoxic $T$ lymphocytes (CTLS) were infused. Viral load in the CNS decreased and the patient recovered from the acute event. In neither case were drug-resistant HCMV variants observed in blood or CNS samples.

Conclusions: T-cell depleted HSCT appears a predisposing condition for CNS HCMV infection since never observed in other HSCT recipients at our center in the last 15 years. Intensive diagnostic approaches and timely aggressive combination treatments might improve clinical outcome in these patients.
\end{abstract}

Keywords: HCMV, CNS, T-cell depleted, HSCT

\section{Background}

Over the last 15 years at our center roughly 800 pediatric and 400 adult patients have received a hematopoietic stem cell transplant (HSCT). Recently, T-cell depletion has been introduced both as a graft manipulation before infusion from haploidentical donors and as an in vivo Tcell depletion in matched unrelated HSCT. While these procedures are not routinely performed, the number of T-cell depleted HSCT has steadily increased over the last 5 years and consisting now about $25 \%$ of all pediatric and $60 \%$ of all adult HSCT performed at out Instition.

It should be noted that, depletion of T-cells before graft infusion or in the post transplant period reduces

\footnotetext{
* Correspondence: f.baldanti@smatteo.pv.it

${ }^{3}$ Struttura Semplice Virologia Molecolare, Struttura Complessa Virologia e Microbiologia, Fondazione IRCCS Policlinico San Matteo, Pavia, Italy Full list of author information is available at the end of the article
}

the risk for graft-versus-host disease (GVHD), but also increases the risk for infectious complications [1,2].

Human Cytomegalovirus (HCMV) infections of the central nervous system (CNS) are rare but life-threatening complications following HSCT [3,4]. The high mortality rate has been associated with immune system impairment and reduced efficacy of antiviral treatment due to the poor bioavailability of ganciclovir (GCV) and foscarnet (PFA) in cerebrospinal fluid (CSF) $[5,6]$. We report on the different outcomes of CNS HCMV infection in two T-cell depleted HSCT recipients.

\section{Case presentations \\ Virologic monitoring and treatment}

All T-cell depleted HSCT recipients undergo frequent virologic monitoring associated with pre-emptive treatment protocols for most common viral infections, such as HCMV [7], EBV [8,9], and adenovirus [10]. 
In more detail, in the absence of active HCMV infection or GVHD, real-time PCR for HCMV DNA quantification in whole blood $[11,12]$ is performed once a week in the first three months post-transplant, once every two weeks in the next three months and once every four weeks in the next six months. In the presence of active HCMV infection or GVHD, real-time PCR is performed twice a week. Treatment with GCV was initiated upon detection of 10,000 HCMV DNA copies in whole blood $[12,13]$.

The emergence of GCV- and PFA-resistant HCMV strains is monitored by sequencing HCMV UL97 and UL54 genes [14].

In all pediatric patients receiving haploidentical HSCT, HCMV- EBV- and adenovirus- specific donor derived CTLs are generated before transplantation and administered in case of refractory infections $[10,15]$.

\section{Patient no. 1}

A HCMV-seropositive 58 year old man with high-risk acute myeloid leukemia received a matched unrelated HSCT from a HCMV-seronegative donor. Transplant conditioning included 200 cGy total body irradiation (TBI), fludarabine, alemtuzumab and melphalan. Cyclosporine and a short course of methotrexate were given as prophylaxis against GVHD. After engraftment, the patient presented with three recurrent asymptomatic HCMV DNAemia episodes $(>10,000$ copies $/ \mathrm{mL})$ and pre-emptive treatment (GCV $5 \mathrm{mg} / \mathrm{kg} /$ twice a day) was administered at days $15-35$, days $69-74$ and days $85-93$. Nine months after transplant, prednisone $(50 \mathrm{mg} / \mathrm{Kg} /$ once a day), polyclonal immunoglobulins (400 $\mathrm{mg} / \mathrm{Kg} /$ every four days) and rituximab (RTX) (600 mg/once a week) were administered to treat thrombocytopenia (PLT $14.000 / \mu \mathrm{L}$ ) in the presence of antibodies to platelet membrane glycoproteins (GPIb/IX and GP IIb/IIIa). On day 396, two months after the last of four RTX doses, the patient showed progressive memory deficit, temporal disorientation, astenia and weight loss. Expansion of the NK cell subset $(1,449$ cells $/ \mu \mathrm{L})$, reduced CD4 (132 cells $/ \mu \mathrm{L})$ and CD8 (79.5 cells $/ \mu \mathrm{L})$ T-cell counts and depletion of CD19 cells ( 0 cells/ $\mu \mathrm{L})$ were observed. Brain Magnetic Resonance Imaging (MRI) showed several foci of restricted diffusion along the ventricles and the ependyma, consistent with encephalitis. Despite blood brain barrier damage (albumin $877 \mathrm{mg} / \mathrm{L}$ CSF), a higher HCMV DNA level $(346,780$ copies/mL) in CSF than in blood $(8,100$ copies $/ \mathrm{mL})$ was observed. GCV treatment $(5 \mathrm{mg} / \mathrm{kg} /$ twice a day) was initiated. On day 407, the emergence of a GCV-resistant HCMV strain was hypothesized based on fever and dyspnoea: thus, GCV was empirically substituted with PFA $(90 \mathrm{mg} / \mathrm{kg} /$ twice a day). On day 418, HCMV DNA became undetectable in blood, but persisted at a high level in CSF (88,920 copies/ $\mathrm{mL}$ ) and PFA treatment was supplemented with anti-
HCMV immunoglobulins. Meanwhile, Staphylococcus epidermidis was isolated in a blood culture. Subsequently, teicoplanin therapy was associated with disappearance of fever and dyspnoea. Sequencing of HCMV UL97 and UL54 showed the absence of drug-resistant HCMV strains in blood or CSF. However, the patient experienced progressive deterioration in neurological function, accompanied by a worsening of the brain MRI. On day 449 after transplantation, HCMV DNA persisted at a high level in CSF $(102,860$ copies $/ \mathrm{mL})$ in parallel with severe blood brain barrier damage (albumin $1,310 \mathrm{mg} / \mathrm{L}$ ). Severe lymphopenia with a predominance of NK cells (228 cells $/ \mu \mathrm{L})$, low numbers of CD8 (5.4 cells $/ \mu \mathrm{L})$ and $\mathrm{CD} 4$ T-cells $(8.5$ cells $/ \mu \mathrm{L})$, and a complete absence of B-cells was observed. Two days later, the patient became unresponsive, developed fever and eventually died. The virologic follow-up is summarized in Figure 1A.

\section{Patient no. 2}

A HCMV-seronegative 4 year old girl who received a haploidentical T-cell depleted HSCT from a HCMVseropositive donor to treat an acute lymphoblastic leukaemia (ALL), which had relapsed five months before. Transplant conditioning included TBI, fludarabine, thiotepa and antithymocyte globulin. No GVHD prophylaxis was administered. After engraftment, on day 24, an HCMV infection was detected in blood (2 pp65-positive cells $/ 200,000$ cells) and treatement with PFA $(90 \mathrm{mg} / \mathrm{kg} /$ twice a day) was initiated. Despite antiviral treatment, HCMV viral load increased (100,500 DNA copies/mL blood on day 59) and donor HCMV-specific CTLs were infused on days 59, 80 and 97. From day 97, GCV (5 mg/kg/ twice a day) was added to PFA. Persistent fever was present from day 90 . On day 102 , very low CD4 (39 cells/ $\mu \mathrm{L})$ and CD8 (33 cells $/ \mu \mathrm{L}$ ) T-cell counts were observed. On day 105 , cutaneous GVHD was diagnosed, and methylprednisolone $(1.5 \mathrm{mg} / \mathrm{kg} /$ once a day) was administered, followed by tacrolimus ( $1 \mathrm{~g} /$ once a day) and three doses of polyclonal immunoglobulin. On day 106, the patient reported acute cervical and right knee pain, accompanied by fever, asthenia and headache. X-ray and CT scan did not show skeletal or neurologic trauma. Tramadol hydrochloride (15 mg intravenously), ketorolac tromethamine (8 $\mathrm{mg}$ intravenously) were ineffective in controlling pain and morphine (2 mg intravenously) was infused on day 106. A high HCMV DNA load (495,900 copies/mL) was detected in CSF in contrast with 9,200 HCMV DNA copies/mL in blood. Sequencing of HCMV UL97 and UL54 showed the absence of drug-resistant HCMV strains in blood or CSF. On day 114 the neurological picture improved, but two weeks later viral load was still elevated. GCV was undetectable in plasma, while it was present at a low basal concentration $(0.55 \mu \mathrm{g} / \mathrm{mL})$ in CSF. On day 132, GCV 


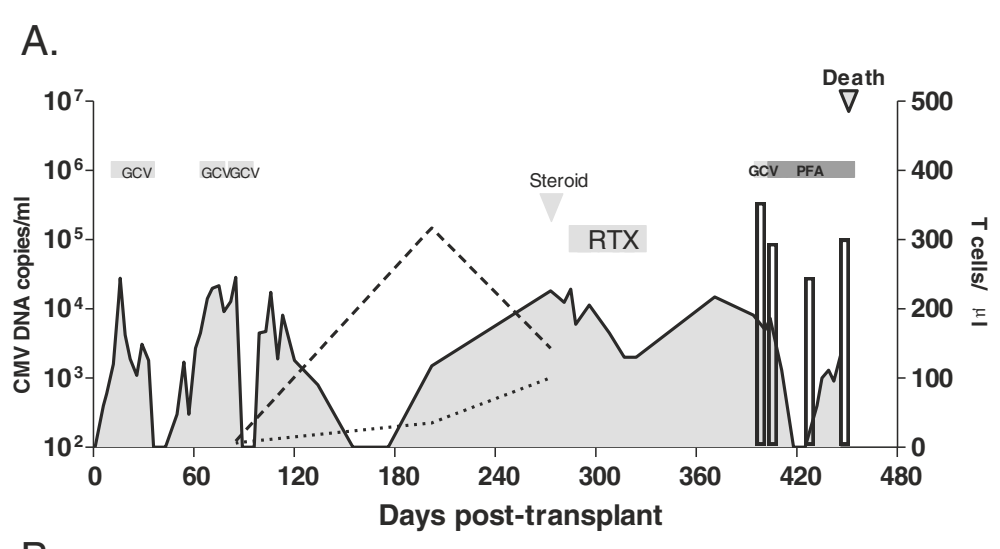

B.

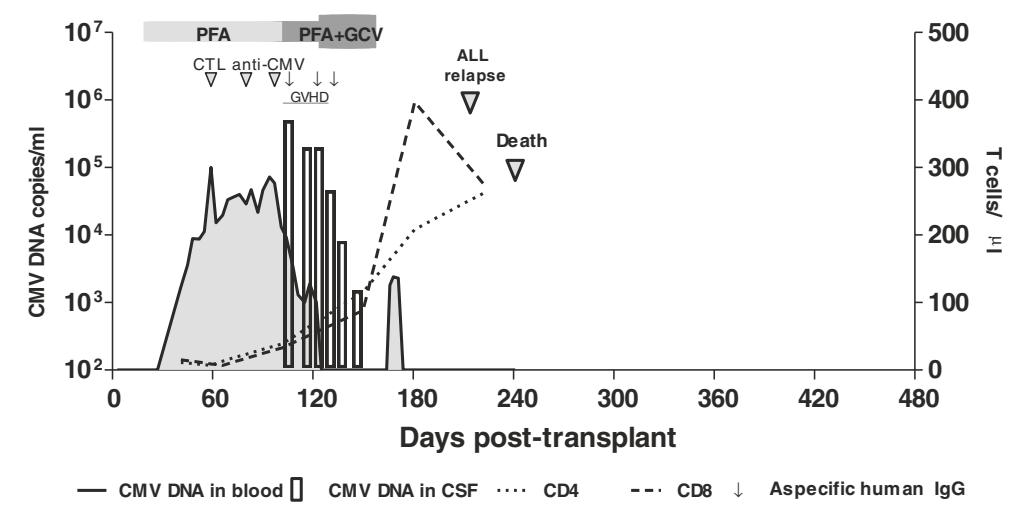

Figure 1 Virologic monitoring of CNS HCMV infection in (A) an adult HSCT and (B) in a pediatric HSCT recipient. The sensitivity of the inhouse developed HCMV DNA Real-Time PCR is 100 copies $/ \mathrm{mL}$ for blood specimens and 20 copies $/ \mathrm{mL}$ for CSF specimens.

was administered at an increased dosage of $7.5 \mathrm{mg} / \mathrm{kg}$ twice a day. HCMV DNA load declined progressively until disappearance, initially in blood (day 132) and then in CSF (day 158). From day 150, T-lymphocyte reconstitution was observed (CD4, 115 cells $/ \mu \mathrm{L}$ and CD8, 88 cells/ $\mu \mathrm{L}$, followed by CD4, 208 cells $/ \mu \mathrm{L}$ and $\mathrm{CD} 8,397$ cells $/ \mu \mathrm{L}$ on day 181). Unfortunately, on day 214, the patient relapsed ALL and died one month later. The virologic follow-up is summarized in Figure 1B.

\section{Conclusion}

Following allogeneic HSCT, HCMV end-organ localization is more commonly characterized by interstitial pneumonia and gastrointestinal disease, while HCMV encephalitis and radiculoneuropathy have been seldomly reported [3]. The pathogenesis of HCMV CNS disease is still debated. Recurrent viremic events may lead to end-organ neurologic syndromes. Sub-optimal CNS antiviral drug penetration along with impaired local immunosurveillance both represent causes of virus latency, uncontrolled viral replication and HCMV disease [6,16,17]. In our patients, this serious complication appeared in the context of persistent and severe T-cell depletion. In addition, in the adult patient, the immune impairment was worsened by $\mathrm{CD} 20$ B-cell depletion.

As also observed in other cases [4], HCMV CNS disease followed the failure of pre-emptive monotherapy to control disseminated HCMV. The emergence of a drug-resistant HCMV strain was suspected, but excluded in both cases. Rescue treatment was more aggressive in the pediatric patient, with the combined administration of PFA, high dose GCV and infusions of HCMV-specific CTL. The GCV dosage was increased due to negligible GCV levels in both blood and CSF. Timely HCMV-specific CTL infusions were possible since at our Institution viral-specific CTLs are generated in advance from the donor in all cases of haploidentical T-cell depleted pediatric transplantation. Unfortunately, for the adult patient the graft was from a bank donor and precluded the possibility to generate in advance specific CTLs.

These two cases confirm the severity of CNS HCMV disease in HSCT recipients. However, they also show that frequent monitoring and timely aggressive treatment interventions based upon combined administration of GCV and PFA and, whenever possible, HCMV-specific CTLs may alter the course of the disease. Plasmatic and 
intrathecal antiviral drug levels should be monitored in order to avoid treatment failure in the absence of drugresistant HCMV strains.

In consideration of the increasing number of patients who will receive an in vivo or in vitro T-cell depleted transplant, new strategies should be urgently adopted to prevent prolonged HCMV immunodeficiency and the emergence of severe HCMV-related complications. New antiviral drugs [18], vaccines [19,20], and reconstitution of HCMV cellular immunity [21-23] should be considered when designing new models of HCMV disease prevention.

\section{Consent}

Written informed consent was obtained from the two patients (from the parents in the pediatric case) for publication. A copy of the written consent is available for review by the Series Editor of this journal.

\section{Abbreviations}

CNS: Central nervous system; CTL: Cytotoxic T lymphocytes; GCV: Ganciclovir; GVHD: Graft-versus-host disease; HCMV: Human cytomegalovirus;

HSCT: Hematopoietic stem cell transplant; MRI: Magnetic resonance imaging; PFA: Foscarnet; TBI: Total body irradiation.

\section{Competing interests}

The authors declare that they have no competing interests.

\section{Authors' contributions}

AAC, GG, PEA and MZ clinical case management and discussion. PV and MRB pharmacokinetics assessment. MF and VR virological analysis and case discussion. AAC, MZ and FB case discussion, data analysis and manuscript writing. FB fund raising. All authors discussed the data, read and approved the final manuscript.

\section{Acknowledgements}

We thank Daniela Sartori for manuscript editing and Laurene Kelly for revision of the English. This work was partially supported by the Ministero della Salute, Ricerca Corrente (grant no. 80207).

\section{Author details}

${ }^{1}$ Centro Trapianti di Midollo Osseo, Istituto di Ematologia, Fondazione IRCCS Policlinico San Matteo, Pavia, Italy. ${ }^{2}$ Struttura Complessa di Ematologia ed Oncologia Pediatrica, Fondazione IRCCS Policlinico San Matteo, Pavia, Italy. ${ }^{3}$ Struttura Semplice Virologia Molecolare, Struttura Complessa Virologia e Microbiologia, Fondazione IRCCS Policlinico San Matteo, Pavia, Italy. ${ }^{4}$ Dipartimento di Farmacologia, Fondazione IRCCS Policlinico San Matteo, Pavia, Italy

Received: 7 June 2012 Accepted: 26 September 2012 Published: 3 October 2012

\section{References}

1. Huang XJ: Current status of haploidentical stem cell transplantation for leukemia. J Hematol Oncol 2008, 31:1-27.

2. Locatelli F, Vinti L, Palumbo G, Rossi F, Bertaina A, Mastronuzzi A, Bernardo ME, Rutella S, Dellabona P, Giorgiani G, Moretta A, Moretta L: Strategies to optimize the outcome of children given T-cell depleted HLA-haploidentical hematopoietic stem cell transplantation. Best Pract Res Clin Haematol 2011, 24:339-349.

3. Schmidt-Hieber M, Schwender J, Heinz WJ, Zabelina T, Kühl JS, Mousset S, Schüttrumpf S, Junghanss C, Silling G, Basara N, Neuburger S, Thiel E, Blau IW: Viral encephalitis after allogeneic stem cell transplantation: a rare complication with distinct characteristics of different causative agents. Haematologica 2011, 96(1):142-149.
4. Reddy SM, Winston DJ, Territo MC, Sciller GJ: CMV central nervous system disease in stem-cell transplant recipients: an increasing complication of drug-resistant CMV infection and protracted immunodeficiency. Bone Marrow Transplant 2010, 45:979-984.

5. Mori T, Kato J: Cytomegalovirus infection/disease after hemopoietic stem cell transplantation. Int J Hematol 2010, 91:588-595.

6. Wolf DG, Lurain NS, Zuckerman T, Hoffman R, Satinger J, Honigman A, Saleh N, Robert ES, Rowe JM, Kra-Oz Z: Emergence of late cytomegalovirus central nervous system disease in hematopoietic stem cell transplant recipients. Blood 2003, 101:463-465.

7. Baldanti F, Lilleri D, Gerna G: Human cytomegalovirus load measurement and its applications for pre-emptive therapy in patients undergoing hematopoietic stem cell transplantation. Hematol Oncol 2008, 26:123-130.

8. Baldanti F, Gatti M, Furione M, Paolucci S, Tinelli C, Comoli P, Merli P, Locatelli F: Kinetics of Epstein-Barr virus DNA load in different blood compartments of pediatric recipients of T-cell-depleted HLA-haploidentical stem cell transplantation. J Clin Microbiol 2008, 46:3672-3677.

9. Comoli P, Basso S, Zecca M, Pagliara D, Baldanti F, Bernardo ME, Barberi W, Moretta A, Labirio M, Paulli M, Furione M, Maccario R, Locatelli F: Preemptive therapy of EBV-related lymphoproliferative disease after pediatric haploidentical stem cell transplantation. Am J Transplant 2007, 7:1648-1655.

10. Comoli P, Basso S, Labirio M, Baldanti F, Maccario R, Locatelli F: T cell therapy of Epstein-Barr virus and adenovirus infections after hemopoietic stem cell transplant. Blood Cells Mol Dis 2008, 40:68-70.

11. Gerna G, Lilleri D, Furione M, Baldanti F: Management of human cytomegalovirus infection in transplantation: validation of virologic cut-offs for preemptive therapy and immunological cut-offs for protection. New Microbiol 2011, 34:229-254.

12. Lilleri D, Gerna G, Furione M, Bernardo ME, Giorgiani G, Telli S, Baldanti F, Locatelli F: Use of a DNAemia cut-off for monitoring human cytomegalovirus infection reduces the number of preemptively treated children and young adults receiving hematopoietic stem-cell transplantation compared with qualitative pp65 antigenemia. Blood 2007, 110:2757-2760.

13. Gerna G, Lilleri D, Caldera D, Furione M, Zenone Bragotti L, Alessandrino EP: Validation of a DNAemia cutoff for preemptive therapy of cytomegalovirus infection in adult hematopoietic stem cell transplant recipients. Bone Marrow Transplant 2008, 41:873-879.

14. Baldanti F, Lurain N, Gerna G: Clinical and biologic aspects of human cytomegalovirus resistance to antiviral drugs. Hum Immunol 2004, 65:403-409.

15. Comoli P, Maccario R, Locatelli F, Grossi P, Baldanti F, Revello MG, Gerna G: Adoptive transfer of Herpesvirusspecific Cytotoxic T Lymphocytes in transplant recipients. Herpes 2000, 7:9-12.

16. Sarva H, Graber J, Remanan R, Rosenblum M, Omuro A: CMV encephalitis in BMT recipients. Bone Marrow Transplant 2012, 47:318-320.

17. Julin JE, van Burik JH, Krivit W, Webb C, Holman CJ, Clark HB, Balfour HH Jr: GCV-resistant cytomegalovirus encephalitis in a bone marrow transplant recipient. Transpl Infect Dis 2002, 4:201-206.

18. Winston DJ, Young JH, Pullarkat V, Papanicolaou GA, Vij R, Vance E, Alangaden GJ, Chemaly RF, Petersen F, Chao N, Klein J, Sprague K, Villano SA, Boeckh M: Maribavir prophylaxis for prevention of cytomegalovirus infetion in allogeneic stem cell transplant recipients: a multicenter, randomized, double-blind, placebo-controlled, dose-ranging study. Blood 2008, 111:5403-5410.

19. Wloch MK, Smith LR, Boutsaboualoy S, Reyes L, Han C, Kehler J, Smith HD, Selk L, Nakamura R, Brown JM, Marbury T, Wald A, Rolland A, Kaslow D, Evans T, Boeckh M: Safety and immunogenicity of a bivalent cytomegalovirus DNA vaccine in healthy adult subjects. J Infect Dis 2008, 197:1634-1642.

20. Go V, Pollard RB: A cytomegalovirus vaccine for transplantation: are we closer? J Infect Dis 2008, 197:1631-1633.

21. Akpek G, Mikulski M, Kleinberg M, Badros A, Yanovich S, Rapoport AP: Cellular therapy with sequential unmanipulated donor lymphocyte infusions in drug-resistant cytomegalovirus (CMV) encephalitis. Blood 2011, 117(21):5772-5774 
22. Leen AM, Heslop HE: Cytotoxic T lymphocytes as immunotherapy in haematological practice. Br J Haematol 2008, 143:169-179.

23. Leen AM, Christin A, Myers GD, Liu H, Cruz CR, Hanley PJ, Kennedy-Nasser AA, Leung KS, Gee AP, Krance RA, Brenner MK, Heslop HE, Rooney CM, Bollard CM: Cytotoxic T lymphocyte therapy with donor T-cells prevents and treats adenovirus and Epstein-Barr virus infections after haploidentical and matched unrelated stem cell transplantation. Blood 2009, 114:4283-4292.

doi:10.1186/1471-2334-12-238

Cite this article as: Colombo et al: Differential outcome of neurological HCMV infection in two hematopoietic stem cell transplant recipients. BMC Infectious Diseases 2012 12:238.

\section{Submit your next manuscript to BioMed Central and take full advantage of:}

- Convenient online submission

- Thorough peer review

- No space constraints or color figure charges

- Immediate publication on acceptance

- Inclusion in PubMed, CAS, Scopus and Google Scholar

- Research which is freely available for redistribution 